\title{
The Implementation of the Policy, Organising, Planning and Implementing, Measuring Performance, Audit and Reviewing (POPMAR) Model in Occupational Health and Safety Risk Management in an Indonesian Batik Company
}

\author{
Implementasi Policy, Organising, Planning and Implementing, Measuring \\ Performances, Auditing, and Reviewing (POPMAR) Model dalam Manajemen \\ Risiko Keselamatan dan Kesehatan Kerja di sebuah Perusahaan Batik di Indonesia
}

\author{
Fandita Tonyka Maharani ${ }^{1,2}$, Zena Lynch ${ }^{2}$ \\ ${ }^{1}$ Public Health Department, Faculty of Health Science, Universitas Pembangunan Nasional Veteran Jakarta \\ J1. Raya Limo, Limo District, Depok, West Java, 16515 Indonesia \\ ${ }^{2}$ Department of Environmental Health and Risk Management, University of Birmingham \\ Edgbaston, Birmingham B15 2TT, United Kingdom
}

\begin{abstract}
Introduction: In 2009, UNESCO declared Batik Indonesia as an Intangible Cultural Heritage of Humanity. This study examines the occupational health and safety hazards and risks that arise in a Batik company based on a case example of a Batik company in Surakarta, Indonesia. In Indonesia, Batik is categorized as traditional attire. Two kinds of Batik are produced - Batik tulis (traditionally handcrafted) and Batik printing, which uses specific printing tools. The UK Health Safety Executive (HSE) risk assessment framework is referred to in this study, which consists of: hazard identification, population exposure, risk evaluation, precaution development, recording findings, and regular appraisal of systems. Methods: Both observation and interviews (of workers) at the Batik company were utilized for this study as well as an independent risk assessment. Results: The findings highlighted physical, ergonomic, chemical, mechanical, and biological hazards, originating from the materials, tools, and working methods utilized in the batik production. Conclusion: Many of the issues highlighted by this study can be addressed via in-depth risk assessment, using the POPMAR model to frame the activities. This approach can create a positive pathway, leading to a continuous cycle of improvement which puts the workers' health at the forefront of the business activities.
\end{abstract}

Keywords: Batik, workers, hazard identification, HSE Model, risk management

\section{ABSTRAK}

Pendahuluan: UNESCO mendeklarasikan Batik Indonesia sebagai warisan dunia tak benda pada tahun 2009. Penelitian ini bertujuan untuk mengidentifikasi bahaya dan risiko K3 yang ada di sebuah perusahaan batik di Surakarta, Indonesia. Di Indonesia, batik dapat dikategorikan sebagai pakaian tradisional. Perusahaan ini memproduksi dua jenis batik - batik tulis (dibuat secara manual oleh perajin) dan batik printing yang menggunakan peralatan printing spesifik. Framework penilaian risiko yang berasal dari The Health Safety Executive (HSE) UK digunakan dalam penelitian ini yang terdiri dari identifikasi bahaya, populasi terpajan, evaluasi risiko, pengembangan tindakan pengendalian, pendokumentasian temuan, dan penilaian sistem secara berkala. Metode: Observasi dan interview pada pekerja digunakan dalam penelitian ini. Observasi dilakukan pada berbagai tahapan proses produksi batik. Interviews dilakukan pada 6 pekerja yang mewakili masing-masing tempat kerja. Hasil: observasi langsung menemukan bahwa material, peralatan, dan metode kerja yang digunakan dari proses produksi batik menghasilkan bahaya fisik, ergonomi, kimia, mekanik, dan biologi. Simpulan: permasalahan yang terjadi di perusahaan dapat diatasi dengan pemahaman yang baik mengenai risiko serta kajiannya dan menerapkan pemodelan POPMAR dalam aktivitas pekerjaan. Hal ini akan membuat pola yang positif yang dapat berkontribusi dalam perbaikan yang berkelanjutan serta menempatkan kesehatan pekerja sebagai prioritas dalam segala aktivitas.

Kata kunci: HSE Model, identifikasi bahaya, manajemen risiko, pekerja batik

Corresponding Author:

Fandita Tonyka Maharani

Email: fanditatonykamaharani@gmail.com

Telephone: +6285747989865

(C2021 IJOSH All right reserved. Open access under CC BY NC-SA license doi:10.20473/ijosh.v10i3.2021.420-432 Received April 23, 2021, received in revised form August 13, 2021, Accepted August 23, 2021, Published: December 2021 


\section{INTRODUCTION}

Batik Indonesia was declared an Intangible Cultural Heritage by UNESCO in 2009. Batik is very much part of the Javanese tradition and The Batik Gaffney (2021) declared Java Island in Indonesia as having the best Batik in the world.

Batik is a method of traditional clothes production involving hot dyed wax being applied to a garment. Handmade batik is created by craftsmen who draw the design, cover the design with hot wax, dye the clothes with the intended colour and then immerse the clothes in hot boiling water. This process is repeated until the garments have the desired colour (UNESCO, 2021).

The Indonesian nation believes that Batik is inseparable to their culture with a deep meaning and guiding philosophy attached to it (Trixie, 2020). Today Batik can also be produced using machine techniques, but the product is not associated the individuality and characteristics of the handcrafted fabric.

According to Lestari (2020), the presence of various hazards in the Batik workplace, including chemical, physical, ergonomic, biological and psychosocial hazards are not only dangerous but can result in lost working hours, productivity reduction and disruption which can lead to financial impacts as well as health impacts. For example, many chemicals are utlised in the production of Batik including Sodium bicarbonate, Sodium carbonate, Sodium hexametaphosphate, Urea, Sodium hydrosulphite, White vinegar, Acetic acid, Ammonium sulphate, and Sodium silicate (Dyrenforth, 2003). Reactive dyes, namely, Remazol, Naphthol, and Indigosol are also included in the Batik production process (Aryanti, 2015).

It has been documented that exposure to the chemicals used in Batik will affect the skin, potentially causing irritation, dryness, itchiness, redness, chemical burns, ulcers, erythema, and occupational dermatitis. Moreover, the chemical fumes can affect the respiratory system which can cause coughing, fever, and even asphyxiation (Lestari, 2010). A study by Soebaryo and Budianti (2020) concluded that batik workers often have dermatitis because of the allergen and irritants from chemicals used in the industry.

As well as the potential exposure to chemicals, Batik craftsmen also have to work in awkward and static positions, which can impact their arm, shoulder, wrist, back, knee, thigh, and foot movement. There is evidence that these awkward positions are associated with Musculoskeletal Disorders (MSDs) (Melese et al., 2020). A study by Maharani et al. (2020), highlighted that the chairs used by Batik workers, known as 'Dingklick', were not ergonomic, and could contribute to musculoskeletal disorders.

A further study conducted by Sari (2015) underpins the issues associated with Batik production. In their research, they found 124 different health and safety concerns including accidents involving hot liquid wax, molten turpentine splashes and sharp tool scratches.

The Indonesian government regulates the health and safety management system through the "UU. No 1 Tahun 1970" (The Regulation concerning safety at the workplace) and "SMK3 PP. No 50 Tahun 2012"
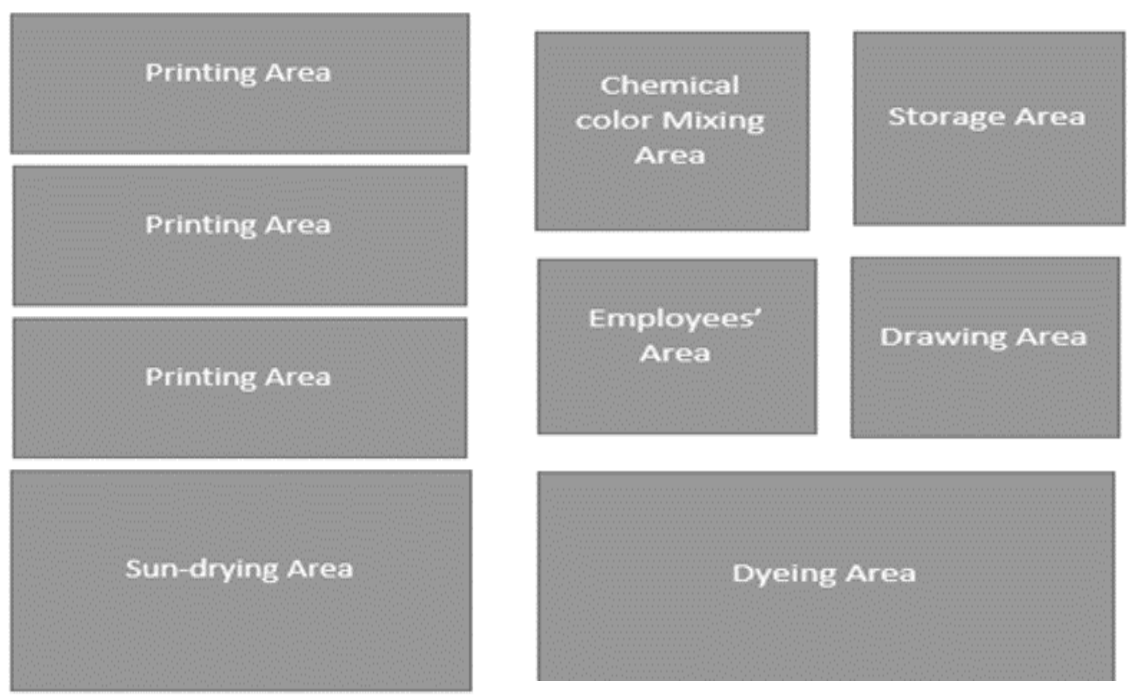

Figure 1. The Company Workplace Layout 
(The Health and Safety Management System within Government Regulations). Data from the Ministry of the Industry, Republic Indonesia (2021) shows that there are an estimated 100,000 workers in batik, with the numbers growing every year. In the study area of Surakarta, Indonesia, there are around 72 batik industries which employ 7.000 people (Lestari, 2010).

The Health and Safety Executive (2016), proposed that health and safety management systems become the key tool for managing workplace health and safety. The HSE management model, based on $\mathrm{HS}(\mathrm{G}) 65$, includes areas of: "policy, organising, planning, measuring performance, and audit and review of performance (Health and Safety Executive, 2013). This management system involves the whole organization and includes assessment of business structure, business activities, responsibilities, practices, processes, procedures and resources. The process also involves mapping and evaluating health and safety achievements, and maintaining the health and safety policy of the organization.

This study aimed to assess the occupational health and safety hazards and risks utlising the POPMAR Model (HSG65) to evaluate the adopted risk management in the selected company. The company chosen for the research study was based in the Surakarta region and was founded in 2000. Its goods are distributed all around Indonesia. The factory is located in a small village and all of the workers employed at the site are from this village.

\section{METHODS}

The methods utilized for this study were direct observation of the working areas to identify the hazards followed by semi-structured interviews to explore the workers opinions with respect to their working environment and health and safety implications. An independent risk assessment was also carried out.

The working areas observed included the dyeing, sun-drying, printing, drawing, chemical color mixing, and Batik tulis areas. The observation data was obtained through both direct observations as well as video footage. Interviews were obtained from six workers, each being a designated leader for their working area. These workers were chosen for their relevant skills, experience, and knowledge of their particular areas of production. The results of the interviews were transcipted with thematic analysis utilized.

\begin{tabular}{ll}
\hline \multicolumn{1}{c}{ Hazard Severity (a) } & $\begin{array}{l}\text { L i k e l i h o o d } \\
\text { Occurrence (b) }\end{array}$ \\
\hline $\begin{array}{l}\text { 1- Trivial (e.g discomfort, slight } \\
\text { bruising, self-help recovery) }\end{array}$ & $\begin{array}{l}\text { 1- Remote (almost } \\
\text { never) }\end{array}$ \\
$\begin{array}{l}\text { 2- Minor (e.g small cut, } \\
\text { abrasion, basic first aid need) }\end{array}$ & $\begin{array}{l}\text { 2- Unlikely (occurs } \\
\text { rarely) }\end{array}$ \\
$\begin{array}{l}\text { 3- Moderate (e.g strain, sparin } \\
\text { incapacitation }>\text { 3 days) }\end{array}$ & $\begin{array}{l}\text { 3- Possible (could occur, } \\
\text { but uncommon) }\end{array}$ \\
4- Seroius (e.g fracture, & 4- Likely (recurrent but \\
hospitalistion $>$ 24 hrs, & frequent) \\
incapacitation $>4$ weeks) & 5- Very Likely (occurs \\
5- Fatal (single or multiple) & frequently) \\
\hline
\end{tabular}

Source: US EPA (2009)

Figure 2. Severity and Likelihood Scale

\section{Risk = Likelihood X Severity}

An independent risk assessment was also carried out for this study, based on the HSE UK HSG65 model, to define the source of the hazards involved. Figure 2 below shows the severity and likelihood scale utilized.

The risk assessment considered the working frequency, duration of the work, and the intensity of each task. The risk given a numerical measure through multiplying the likelihood of an occurrence by the severity of the outcome.

\section{RESULTS}

\section{Risk Assessment Results}

Tables 1 below show the hazards found in the dying area, the printing area, the chemical colouring area and the batik tulis area.

\section{Observation Results}

\section{Sun-drying Area}

The processes in this area involving carrying and setting out the fabrics. This involved repetitive lifting, bending, and squatting. There was a particular impact from the heat and one worker observed was repetitively wiping sweat away with his already wet clothes. The lifting and carrying was all done manually without any lifting aids.

In the dyeing area there was a repetitive immersing process in the dying pond which consisted of coloured liquids. It was observed that a worker had to repeatedly stretch his hands and 


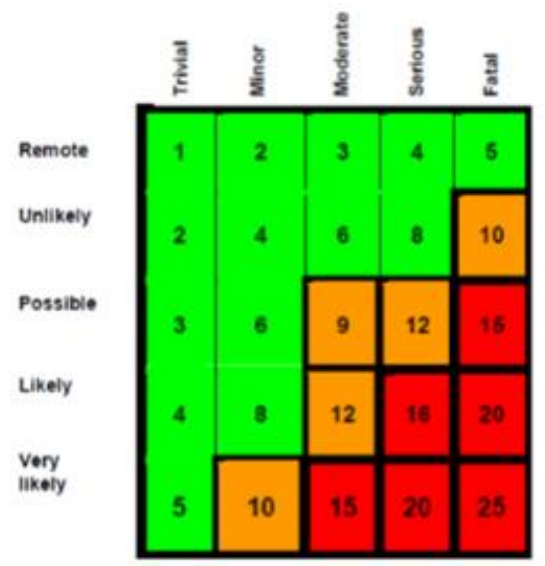

\begin{tabular}{|c|c|c|}
\hline \multicolumn{3}{|c|}{ Rating Bands $(\mathrm{a} \times \mathrm{b})$} \\
\hline $\begin{array}{c}\text { LOW RISK } \\
(1-8)\end{array}$ & $\begin{array}{c}\text { MEDIUM RISK } \\
(9-12)\end{array}$ & $\begin{array}{l}\text { HIGH RISK } \\
(15-25)\end{array}$ \\
\hline $\begin{array}{l}\text { Continue, but } \\
\text { review } \\
\text { perodically to } \\
\text { ensure controls } \\
\text { remain effective }\end{array}$ & $\begin{array}{l}\text { Continue, but } \\
\text { implement } \\
\text { additonal } \\
\text { reasonably } \\
\text { practicabie } \\
\text { controls where } \\
\text { possole and } \\
\text { montor regularly }\end{array}$ & $\begin{array}{l}\text { STOP THE } \\
\text { ACTIVITY. } \\
\text { Identify new } \\
\text { controls. Activity } \\
\text { must not } \\
\text { procoed until } \\
\text { risks are } \\
\text { reduced to a low } \\
\text { or medium level }\end{array}$ \\
\hline
\end{tabular}

Source: US EPA (2009)

Figure 3. Risk Measurement

\begin{tabular}{|c|c|c|c|c|c|c|c|}
\hline $\begin{array}{c}\text { What are the } \\
\text { Hazards? }\end{array}$ & $\begin{array}{c}\text { H a z a r d } \\
\text { S o u r c e } \\
\text { (Equipment/ } \\
\text { Process) }\end{array}$ & $\begin{array}{c}\text { Who might } \\
\text { be harmed } \\
\text { and how? }\end{array}$ & Likelihoood & Severity & Risk & Effects & $\begin{array}{c}\text { E x is t i n g } \\
\text { Control }\end{array}$ \\
\hline & & & & & & & \\
\hline & & & & & & & \\
\hline & & & & & & & \\
\hline & & & & & & & \\
\hline
\end{tabular}

Figure 4. Risk Assessment

arms to completely immerse the fabrics. The edge of the dying pond was low, which meant the worker needed to repeatedly bend over to immerse the fabrics. The immersing process was conducted with bare hands and the worker wore sandals which did not completely protect the feet. Written instructions were observed in this area that people should be very careful due to the wet and slippy floor conditions.

The second task performed in the dyeing area was to immerse the garments into hot water. A worker sat and waited for the immersed clothes to boil. He repeatedly fanned himself with his clothes. It was observed that all the workers in this space wore open sandals.

\section{Drawing Area}

The drawing area was divided into two parts: computer and manual drawing. The computer-based drawing area appeared to be disorganized and a dingklik chair in which the worker was sitting for long periods of time.

In the manual drawing room there was more movement, with the worker moving around the table. The worker was repeatedly bending his back. However, positively, a worker was singing and humming, as if he was enjoying himself.

\section{Printing Area}

The fabrics were placed on five long rows of tables in the printing area. The coloured dye was poured into the wooden printing tool and applied to the fabric. The process was observed to be repetitive. The staff in this area were not wearing any PPE. The workers also appeared to be experiencing problem from the heat as they repetitively dabbed their sweat away.

\section{Chemical Colour Mixing Area}

In this area plastic spoons were used to retrieve the powdered chemicals (sodium carbonate, Alumunium Potassium Sulfate, Reactive Orange 16, Reactive Blue 19, Reactive Red 120) for the dyeing process. The worker wore a fabric mask over his mouth and sandals on his feet, but no other PPE was evident. Electric cables were observed hanging near vessels containing chemicals.

\section{Batik Tulis Drawing Area in the Village}

Additional observation was carried out in a local village house as the Batik tulis (which is bought by the company from the villagers) was being created (this is traditionally created by women). 


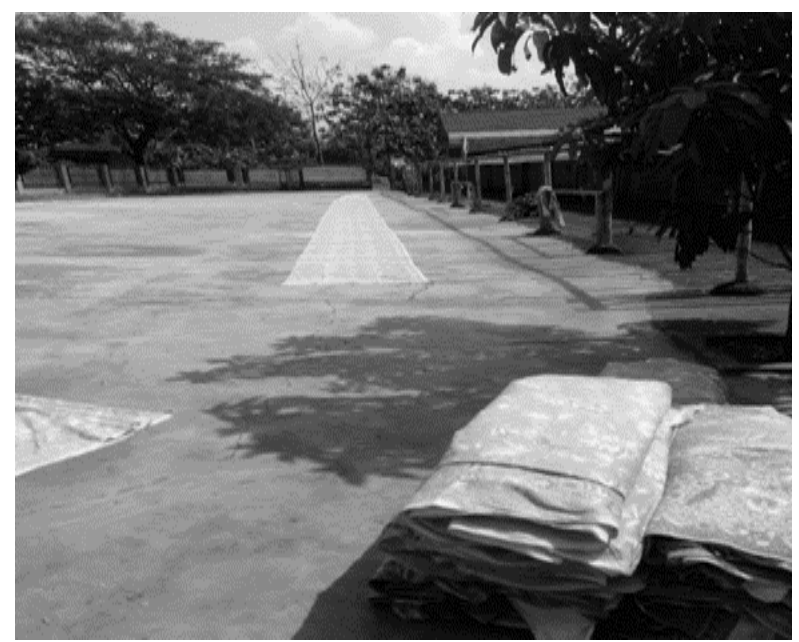

Figure 5. Sun-Drying Area

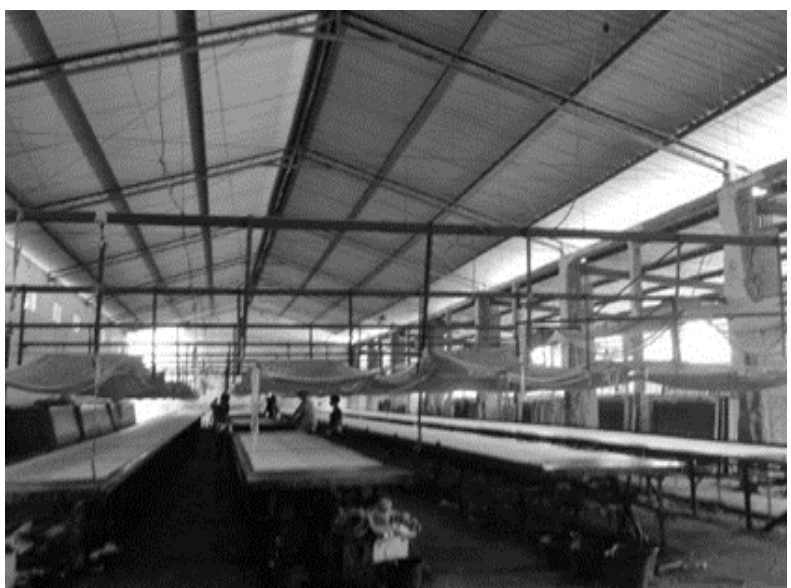

Figure 7. Printing Area

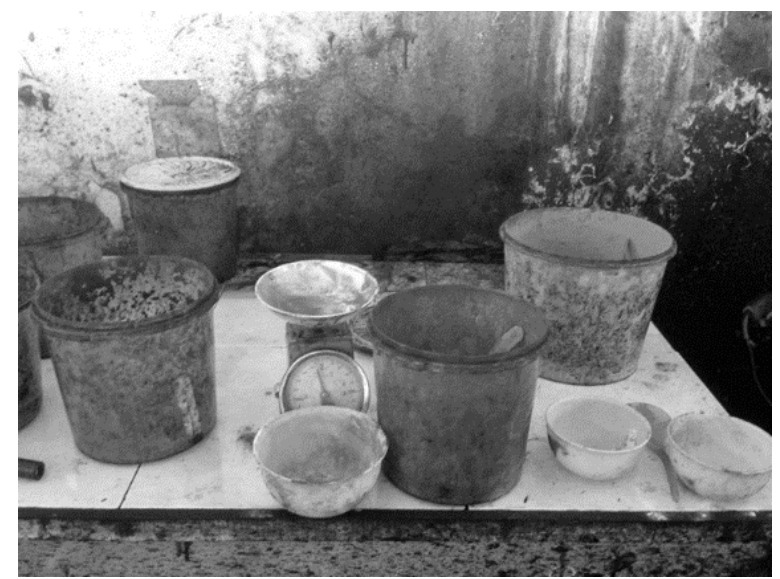

Figure 8. Chemical Color Mixing Area

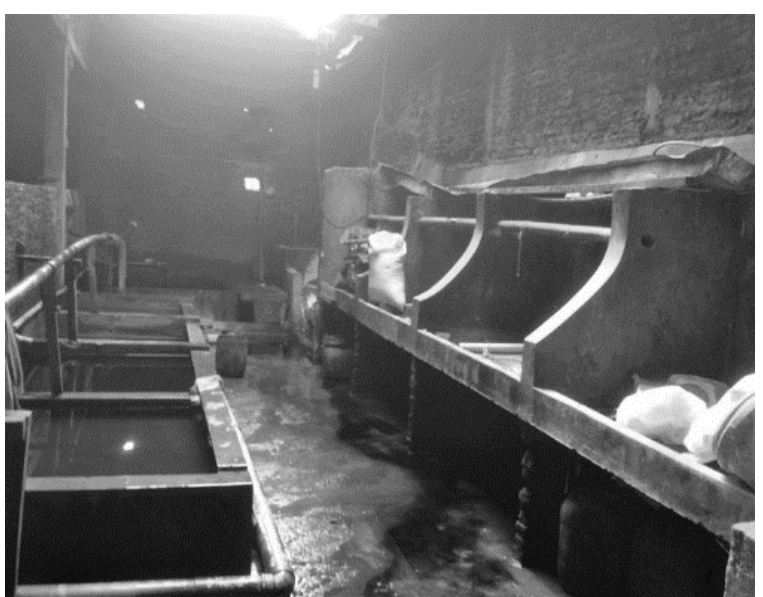

Figure 6. Dyeing Area

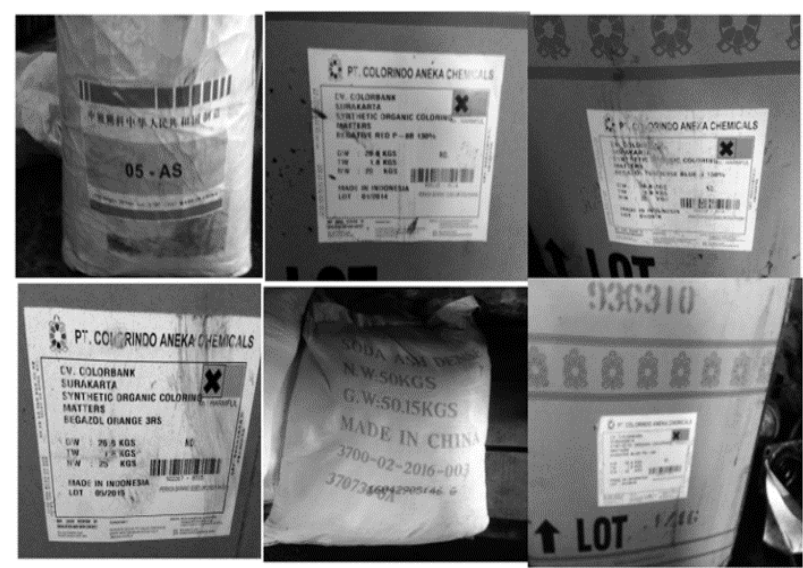

Figure 9. The Chemical Used

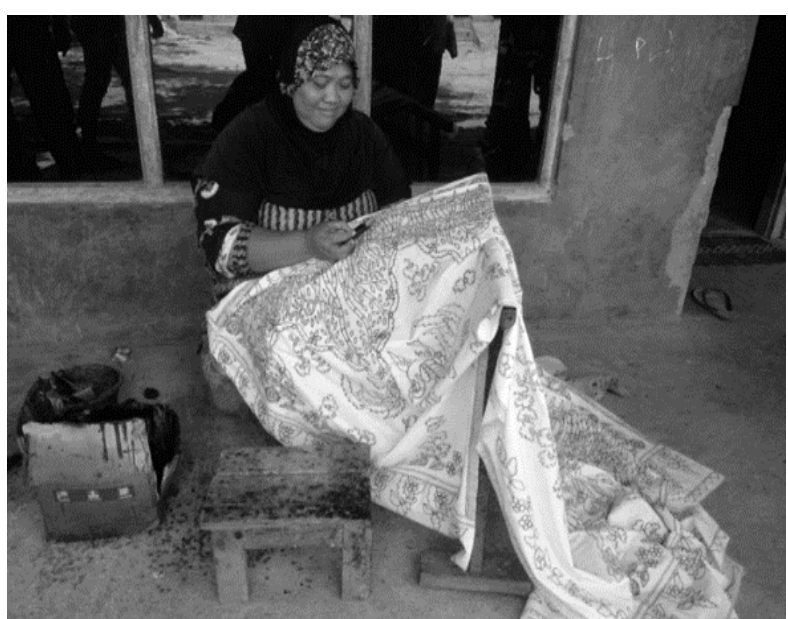

Figure 10. A Village Woman was Making 'Batik Tulis' 
Table 1. Risk Assessment

\begin{tabular}{|c|c|c|c|c|c|c|}
\hline $\begin{array}{l}\text { Workplace } \\
\text { Area }\end{array}$ & Hazards Present & Likelihoood & Severity & Risk & Effects & $\begin{array}{c}\text { E } x \text { is } t \text { i n } g \\
\text { Control }\end{array}$ \\
\hline \multirow[t]{3}{*}{ Heat stress } & Heat stress & 5 & 1 & $\begin{array}{l}5 \text { (low } \\
\text { risk) }\end{array}$ & $\begin{array}{l}\text { Limited concentration, } \\
\text { cramps in the muscle, heat } \\
\text { rash, thirst, fainting, heat } \\
\text { exhaustion, heat stroke (HSE, } \\
\text { 2016) }\end{array}$ & None \\
\hline & Ergonomic & 5 & 1 & $\begin{array}{l}5 \text { (low } \\
\text { risk) }\end{array}$ & Musculoskeletal Disorder & Trolley \\
\hline & Hand-pinched & 4 & 2 & $\begin{array}{l}8 \text { (low } \\
\text { risk) }\end{array}$ & Small Cut & None \\
\hline \multirow{9}{*}{ Dyeing } & Mechanical & 5 & 3 & 15 (high) & Slips, trips, falls & $\begin{array}{l}\text { Mopping the } \\
\text { floor }\end{array}$ \\
\hline & Biological & 5 & 1 & 5 (low) & $\begin{array}{l}\text { Skin problems because of } \\
\text { humid conditions (for example } \\
\text { ringworm) }\end{array}$ & none \\
\hline & Ergonomic & 5 & 3 & 15 (high) & Musculoskeletal Disorder & none \\
\hline & $\begin{array}{l}\text { Sodium Carbonate } \\
\text { (Soda Ash) }\end{array}$ & 5 & 3 & 15 (high) & $\begin{array}{l}\text { Cough, sore throat, redness } \\
\text { in contact with skin, eye pain } \\
\text { and redness, and burning } \\
\text { sensation in the throat and } \\
\text { chest when ingested. }\end{array}$ & $\begin{array}{l}\text { Occasionally } \\
\text { staff use a } \\
\text { mask made } \\
\text { from thin } \\
\text { fabric }\end{array}$ \\
\hline & $\begin{array}{l}\text { Tawas (Aluminum } \\
\text { Potassium Sulfate) }\end{array}$ & 5 & 3 & 15 (high) & $\begin{array}{l}\text { Skin, respiratory track, eyes, } \\
\text { and digestive track irritation }\end{array}$ & $\begin{array}{l}\text { Occasionally } \\
\text { staff use a } \\
\text { mask made } \\
\text { from thin } \\
\text { fabric }\end{array}$ \\
\hline & Reactive Orange 16 & 5 & 3 & 15 (high) & $\begin{array}{l}\text { Sensitisation, irritation } \\
\text { to the eyes, respiratory } \\
\text { system, and skin, fire and } \\
\text { explosion if mixture with } \\
\text { air, may emit poisonous and } \\
\text { corrosive fumes (Santa Cruz } \\
\text { Biotechnology, 2011) }\end{array}$ & none \\
\hline & Reactive Blue 19 & 5 & 3 & 15 (high) & $\begin{array}{l}\text { may cause irritation to the } \\
\text { eyes, skin, digestive tract, } \\
\text { and respiratory tract, an } \\
\text { experimental carcinogen, } \\
\text { may release irritating and } \\
\text { highly toxic gases when on } \\
\text { fire (National Center for } \\
\text { Biotechnology Information, } \\
\text { 2016) }\end{array}$ & none \\
\hline & Reactive Red 120 & 5 & 3 & 15 (high) & $\begin{array}{l}\text { may cause eye discomfort, } \\
\text { conjunctivitis (prolonged } \\
\text { and repeated exposure), } \\
\text { may irritate the respiratory } \\
\text { tract, associated with the } \\
\text { development of bladder } \\
\text { cancer, may emit toxic } \\
\text { fumes when combusted and } \\
\text { decompose (Santa Cruz } \\
\text { Biotechnology, 2011) }\end{array}$ & none \\
\hline & Heat stress & 5 & 1 & 5 (low) & $\begin{array}{l}\text { Lack of concentration, } \\
\text { muscle cramps, heat rash, } \\
\text { severe thirst, fainting, heat } \\
\text { exhaustion, heat stroke (HSE, } \\
\text { 2016) }\end{array}$ & \\
\hline
\end{tabular}


Continued Table 1. Risk Assessment

\begin{tabular}{|c|c|c|c|c|c|c|}
\hline Workplace Area & Hazards Present & Likelihood & Severity & Risk & Effects & $\begin{array}{c}\text { Ex i s t i n } g \\
\text { Control }\end{array}$ \\
\hline \multirow{8}{*}{ Printing } & Heat Stress & 5 & 1 & 5 (low) & $\begin{array}{l}\text { Limited concentration, } \\
\text { cramps in the muscle, } \\
\text { heat rash, severe thirst, } \\
\text { fainting, heat exhaustion, } \\
\text { heat stroke (HSE, 2016) }\end{array}$ & none \\
\hline & $\begin{array}{l}\text { Sodium Carbonate } \\
\text { (Soda Ash) }\end{array}$ & 5 & 3 & 15 (high) & $\begin{array}{l}\text { Sore and burning } \\
\text { sensation in the throat, a } \\
\text { cough, problems in the } \\
\text { eye involving pain and } \\
\text { redness, skin problem, and } \\
\text { burning sensation in the } \\
\text { chest when ingested }\end{array}$ & $\begin{array}{l}\text { Occasionally } \\
\text { staff use a } \\
\text { mask made } \\
\text { from thin } \\
\text { fabric }\end{array}$ \\
\hline & $\begin{array}{l}\text { Tawas } \\
\text { (Alumunium } \\
\text { Potassium Sulfate) }\end{array}$ & 5 & 3 & 15 (high) & $\begin{array}{l}\text { Irritation to the skin, } \\
\text { eyes, digestive track, and } \\
\text { respiratory tract }\end{array}$ & $\begin{array}{l}\text { Occasionally } \\
\text { staff use a } \\
\text { mask made } \\
\text { from thin } \\
\text { fabric }\end{array}$ \\
\hline & $\begin{array}{l}\text { Reactive Orange } \\
16\end{array}$ & 5 & 3 & 15 (high) & $\begin{array}{l}\text { Problems in the eyes } \\
\text { including sensitization } \\
\text { and irritation, problems in } \\
\text { the respiratory system and } \\
\text { skin. When in contact with } \\
\text { the air, fire and explosion } \\
\text { might occur. Furthermore, } \\
\text { poisonous and corrosive } \\
\text { fumes might resulted as } \\
\text { well. } \\
\text { (Santa Cruz } \\
\text { Biotechnology, 2011) }\end{array}$ & none \\
\hline & Reactive Blue 19 & 5 & 3 & 15 (high) & $\begin{array}{l}\text { Problems in the skin, } \\
\text { eyes, digestive track, } \\
\text { and respiratory system } \\
\text { such as irritation might } \\
\text { occur. Highly toxic gases } \\
\text { if fire occurs (National } \\
\text { Center for Biotechnology } \\
\text { Information, 2016) }\end{array}$ & none \\
\hline & Reactive Red 120 & 5 & 3 & 15 (high) & $\begin{array}{l}\text { Eye discomfort might } \\
\text { occurIf exposed repeatedly } \\
\text { over a prolonged period, } \\
\text { conjunctivitis might } \\
\text { occur. The respiratory } \\
\text { tract might be affected } \\
\text { as well. The substance is } \\
\text { associated with bladder } \\
\text { cancer. The substance } \\
\text { might release toxic fumes } \\
\text { when combusted and } \\
\text { decayed (Santa Cruz } \\
\text { Biotechnology, 2011). }\end{array}$ & none \\
\hline & Disorganized Area & 5 & 3 & 15 (high) & Slips, trips, falls & none \\
\hline & $\begin{array}{l}\text { The gas-fueled } \\
\text { drying machine }\end{array}$ & 5 & 2 & $\begin{array}{c}10 \\
\text { (medium) }\end{array}$ & Burned skin & none \\
\hline
\end{tabular}


Continued Table 1. Risk Assessment

\begin{tabular}{|c|c|c|c|c|c|c|}
\hline Workplace Area & Hazards Present & Likelihood & Severity & Risk & Effects & Existing Control \\
\hline \multirow{6}{*}{$\begin{array}{l}\text { Chemical Color } \\
\text { Mixing }\end{array}$} & $\begin{array}{l}\text { Sodium Carbonate } \\
\text { (Soda Ash) }\end{array}$ & 5 & 3 & 15 (high) & $\begin{array}{l}\text { Burning sensation and sore } \\
\text { in the throat, cough, skin } \\
\text { problems, pain and redness } \\
\text { in the eye, and burning }\end{array}$ & $\begin{array}{l}\text { Thin fabric masks } \\
\text { are occasionally } \\
\text { worn by the staff }\end{array}$ \\
\hline & $\begin{array}{l}\text { Tawas (Alumunium } \\
\text { Potassium Sulfate) }\end{array}$ & 5 & 3 & 15 (high) & $\begin{array}{l}\text { Potential irritation to the } \\
\text { eyes, skin, digestive, and } \\
\text { respiratory tract }\end{array}$ & $\begin{array}{l}\text { Thin fabric masks } \\
\text { are occasionally } \\
\text { worn by the staff }\end{array}$ \\
\hline & Reactive Orange 16 & 5 & 3 & 15 (high) & $\begin{array}{l}\text { May irritate and sensitize } \\
\text { the eyes, skin, and the } \\
\text { repiratory system. Fire and } \\
\text { explosion might occur if in } \\
\text { contact with air. Poisonous } \\
\text { and corrosive fumes might } \\
\text { resulted (Santa Cruz } \\
\text { Biotechnology, 2011). }\end{array}$ & none \\
\hline & Reactive Blue 19 & 5 & 3 & 15 (high) & $\begin{array}{l}\text { Eye,skin, digestive, and } \\
\text { respiratory tract irritation } \\
\text { might occur. Toxic gases } \\
\text { occur when combusted } \\
\text { (National Center for } \\
\text { Biotechnology Information, } \\
\text { 2016) }\end{array}$ & none \\
\hline & Reactive Red 120 & 5 & 3 & 15 (high) & $\begin{array}{l}\text { Eye discomfort might } \\
\text { occur.If exposed repeatedly } \\
\text { on prolonged period, } \\
\text { conjunctivitis might occur. } \\
\text { Respiratory problems can } \\
\text { occur and the substance } \\
\text { is associated with the } \\
\text { risk of bladder cancer. } \\
\text { Toxic fumes occur when } \\
\text { combusted and decayed } \\
\text { (Santa Cruz Biotechnology, } \\
\text { 2011) }\end{array}$ & none \\
\hline & $\begin{array}{l}\text { Cable of Electronic } \\
\text { Mixer }\end{array}$ & 5 & 3 & 15 (high) & Electric shock & none \\
\hline \multirow{4}{*}{ Batik Tulis } & Ergonomic & 5 & 3 & 15 (high) & Musculoskeletal Disorders & none \\
\hline & The hot wax fumes & 5 & 2 & $\begin{array}{c}10 \\
\text { (medium) }\end{array}$ & $\begin{array}{l}\text { Eyes and respiratory system } \\
\text { may get irritated (Soebaryo } \\
\text { and Budianti, 2020) }\end{array}$ & none \\
\hline & $\begin{array}{l}\text { The hot wax and } \\
\text { hot tools }\end{array}$ & 5 & 2 & $\begin{array}{c}10 \\
\text { (medium) }\end{array}$ & $\begin{array}{l}\text { The hot wax and hot tools } \\
\text { may cause skin burns' skin }\end{array}$ & none \\
\hline & Disorganized Area & 5 & 3 & 15 (high) & Slips, Trips, Falls & none \\
\hline
\end{tabular}

At the village house, wax was melted on a domestic stove and was used to draw the patterns. It was observed that the 'dingklik', a traditional chair which has no backrest and armrest was used for sitting. The working process required the woman creating the Batik tulis to twist and bend her body, stretch her arms and hands, and sit in prolonged, static, and awkward position.

\section{Interview Results}

Six workers, each with responsibility for a different area of the site were chosen for interview. All of the interviewees were male and had long experience in their job role. Interviews were carried out to better understand risks from the workers perspective. 
There were varying responses from the workers, with respect to the perception of risk as follows:

"I think the chemicals are not dangerous." (worker 4).

"I use the fabric mask because the substance is harmful"(worker 1).

Some health problems were reported by the workers, including skin problems (itchiness and redness), respiratory issues (cough), stiffness, fatigue, headache, tiredness and weariness:

"I feel fatigue and tired at the end of the shift because I must ensure that the colour liquid absorb in them. The process must be conducted 2530 times." (worker 2)

"The skin problems will disappear after a while s. I think we have some kind of adaptation to it." (worker 3).

"I feel dizziness occasionally so I drink plenty of milk to improve my condition..." (worker 3)

There were comments about the housekeeping and maintenance in the factory:

"The trolley is not used because of the rust present and it just disturbs my work." (worker 4)

"I have 20 years working experience. My former workstation was neater than this. This upsets me." (worker 5).

The workers reported the high staff turnover which could affect productivity and suggested the need for more support:

"...After developing some skin problems, the majority of the new recruits will quit after a month or so." (worker 6).

"I will use the over counter medicine when I feel sick. The company does not provide the medical costs." (worker 1).

\section{DISCUSSION}

One of the emerging findings from this study is around the lack of available information regarding the risks associated with the production of Batik. This corresponds with a previous studies by Susilowati (2014), Anis et al, (2013) and Afriansyah (2013) who found that workers in Batik are lacking safety information all of which contributes to safety perception and attitudes

This study also found chemical, physical, biological, ergonomic and mechanical hazards present in the Batik factory. The findings correspond with those of Sari (2014) who found well over 100 occupational hazards (2015). John et al., (2020)

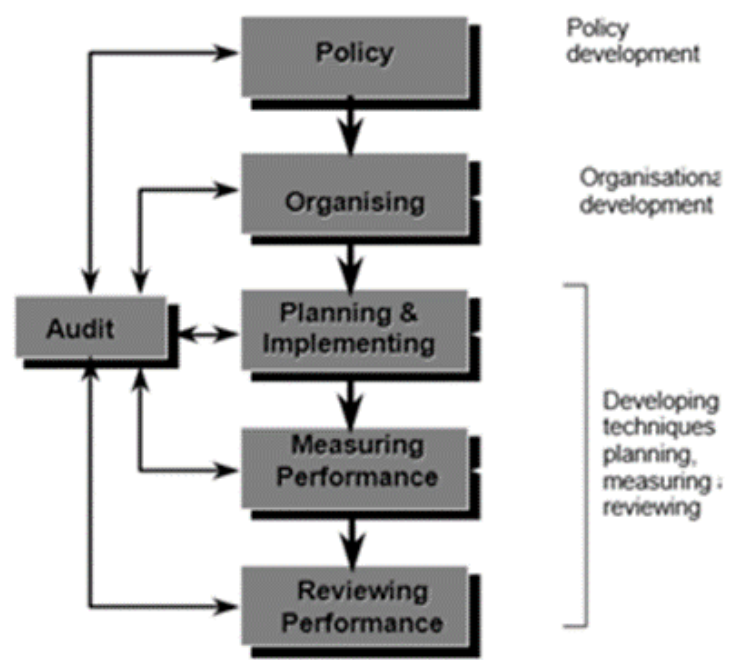

Source: Health and Safety Executive

Figure 11. .HSE Model (HSG65)

reported sources of health hazards corresponding to this study including ergonomic issues, lack of lighting, concern related to room temperature, as well as humidity affecting ears, nose, skin, and throat (John et al., 2020). Agustina, Maulana and Trunojoyo, (2012) also reported the effect of the heat, ergonomic issues and the impact of harmful chemicals.

There are several other studies that correspond with the reported findings of this study, including Soebaryo (2012) who found that from their study that $18.2 \%$ of batik workers develop dermatitis. Perdana (2013) found that $75 \%$ batik workers reported pain in their necks, $10 \%$ reported back problems, $5 \%$ reported problems with their hips, and $10 \%$ with problems elsewhere in the body.

Workers interviewed in this study reported a high turnover of staff, with health issues such as dermatitis being a determinant around this. Bayram, Ünğan and Ardıç (2017) discuss how expensive this turnover is to a business due to the fee implications of replacing staff, productivity loss, workplace health and safety problems as well as morale damage. A study by Mabindisa, 2013 also found that high level of staff turnover affect the companies' image (Mabindisa, 2013).

Health and Safety Management systems have been shown to be effective in reducing the number of accidents in the workplace and have also been linked to more positivity amongst the workforce and evidence is presented in studies by Yoon et al (2013) and Day and Nielson (2017) corresponding with this. The POPMAR Model (HSG65), shown in Figure 11 below has been shown to have benefits in 


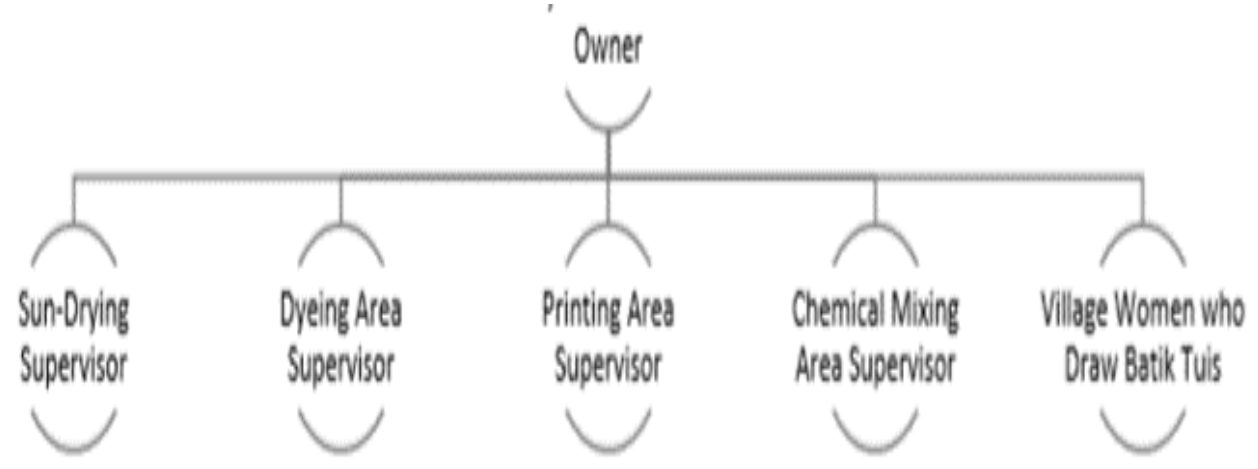

Figure 12. .The Company Management

this respect. (Yoon et al., 2013) (Buica et al., 2017) (Yiu et al., 2019).

Each area of the POPMAR model discussed in more detail against the research findings is below:

\section{Policy}

According to the Health and Safety Executive (2013) it is fundamental for a company to develop a health and safety policy because it sets the clear goal and direction for improved outcomes. Importantly, this model advocates for the director of the company sign off the written policies. Osbourne and Hammond (2017) underpin the importance of this as well as the visibility of these policies in the workplace.

\section{Organizing}

Having clear management arrangements and structures has been shown to contribute to effective communication and improve workers' engagement and participation with health and safety (Walden, Jung and Westerman, 2017; Osborne and Hammoud, 2017). The Health and Safety Executive (2013) state that "the actions in the 'Organizing' stage are divided into methods of control in the organisation, the cooperation between stakeholders, the communication method in the organisation, and the individual's competence". For the Batik company studied, the organizational structure in existence would benefit with communication and dissemination of information by having a supervisor in each area (other than for the village women).

However, as well as good communication routes, appropriate 'competence' must also be ensured to guarantee that the workers have the adequate capabilities to understand and relay health and safety messages.

From the interviews, it was evident that staff acquired their skills from their prior profession but there appeared to be less awareness around health and safety issues. For example, there was some knowledge that the chemical substances might be harmful to their skin but were unclear on how to protect themselves against this.

\section{Planning and Implementation}

The Health and Safety Executive (2013) states that this stage is thinking about the goals and considering how practically we might achieve them. This involves consideration of appropriate action controls, including importantly conducting a risk assessment. This can be linked to the ALARP (As Low as Reasonably Practicable) principle which sets out to put in place the best controls as far as practical to reduce the risk, carefully considering cost-benefit of different approaches.

As part of the planning and implementing stage of POPMAR, the process of documenting the findings is a significant step. By recording, inspecting, monitoring, and maintaining good records of hazards and risks, the company can show an auditable trail which helps with show compliance with the regulations, as well as creating good corporate responsibility and a caring outlook.

\section{Measuring and Reviewing Performance}

The final stage of the POPMAR model is to ensure that the actions proposed are being implemented. The company must measure their performance against the actions taken. (HSE UK, 2013). Ismail and Measures (2020) mention that work processes must be measured and evaluated to know their impact. Burdyny and Smith (2019) refer to this process creating a better designed working environment. Companies carrying out such evaluation are linked to an organizational climate for innovation (Shanker et al., 2017) 


\section{CONCLUSION}

In this study, we found, through observation that there were chemical, biological, physical (including ergonomic) and mechanical hazards, with varying levels of control and management in place. The workers in the had limited information about the existing health and safety issues and in some cases were unaware of the risks. Some workers had experienced health problems related to the tasks they were undertaking.

Many of the issues highlighted can be addressed by a good understanding of the risks involved, together with an in-depth risk assessment, utilizing the POPMAR model to frame the activities. This creates a positive path that can lead to a continuous cycle of improvement and puts the workers' health at the forefront of the activities.

\section{ACKNOWLEDGMENTS}

The authors wish to thank all those that participated at the batik company and to the owner for allowing the study to be carried out.

\section{REFERENCES}

Afriansyah, A. et al. (2013) Manajemen Kesehatan Dan Keselamatan Kerja di PT. APAC INTI CORPORA. Scientific Articles. Surakarta: Faculty of Medicine, Universitas Sebelas Maret.

Agustina, F. and Maulana, A. (2012) 'Analisis Postur Kerja dengan Tinjauan Ergonomi di Industri Batik Madura', Jurnal Inovasi dan Kewirausahaan, 1(3), pp. 167-171.

Anis, M., Wijaya, G. G. and Muslimah, E. (2015) 'Implementasi Kesehatan dan Keselamatan Kerja (K3) di Industri Batik (Studi Kasus di Industri Batik "GT" Laweyan Surakarta', in Seminar Nasional IENACO, pp. 139-147.

Aryanti, N. et al. (2015) 'Micellar-Enhanced Ultrafiltration Membrane (MEUF) of Batik Wastewater using Cetylpyridinium Chloride Surfactant', in AIP Conference Proceedings.

Bayram, M., Ünğan, M. C. and Ardıç, K. (2017) 'The Relationships between OHS Prevention Costs, Safety Performance, Employee Satisfaction and Accident Costs', International Journal of Occupational Safety and Ergonomics, 23(2), pp. 285-296.

Buica, G. et al. (2017) 'Occupational Health and Safety Management in Construction Sector - The
Cost of Work Accidents', Quality - Access to Success, 18(January (S1)), pp. 35-40.

Burdyny, T. and Smith, W. A. (2019) 'CO2 Reduction on Gas-Diffusion Electrodes and Why Catalytic Performance must be Assessed at CommerciallyRelevant Conditions', Energy and Environmental Science, 12(5), pp. 1442-1453.

Climate Institute (2021).

Day, A. and Nielsen, K. (2017) 'What Does Our Organization Do to Help Our Well-Being? Creating Healthy Workplaces and Workers', in An Introduction to Work and Organizational Psychology. United Kingdom: John Wiley \& Sons, Ltd, pp. 295-314.

Dominick E. Fazarro, Walt Trybula, Jitendra Tate, Craig Hanks, C. M. S. (2017) '5. Certification: Validating Workers' Competence in Nano-safety', in Nano-Safety.

Dyrenforth, N. (2003) Batik: Modern Concepts and Techniques - Noel Dyrenforth - Google Buku. London : Batsford.

Gaffney, D. (2021) What is Batik?, The Batik Guild.

Health and Safety Executive (2013) Managing for Health and Safety (HSG65). London: The National Archives.

Health and Safety Executive (2016) Risk Assessment, Health and Safety Executive.

Ismail, H. N. (2020) Evaluation Measures and Approaches for Design Process Performance. Sientific Article. Malaysia: Ministry of Education Malaysia.

John, S. M. et al. (2020) Kanerva's Occupational Dermatology.

Kanerva, L. (2000) Handbook of Occupational Dermatologyy.

Lestari, F. (2010) Bahaya Kimia Sampling dan Pengukuran Kontaminan di Udara. Jakarta: Penerbit Buku Kedokteran EGC.

Litman, R. S. (2019) 'Use of a Public Health Law Framework to Improve Medication Safety by Anesthesia Providers', Journal of Patient Safety and Risk Management, 24(4), pp. 158-165.

Mabindisa, V. (2013) Impact of Staff Turnover on Organisational Effectiveness and Employee Performance at the Department of Home Affairs in the Eastern Cape Province. Thesis. Durban: Faculty of Management Sciences, Durban University of Technology.

Maharani, F. T. et al. (2020) 'The Intervention of Chair and "Gawangan" Among Batik Workers at a Company in Indonesia', in Proceedings of the 
International Conference of Health Development, pp. $135-152$.

Marchand, A., Demers, A. and Durand, P. (2005) 'Do Occupation and Work Conditions Really Matter? A Longitudinal Analysis of Psychological Distress Experiences Among Canadian Workers', Sociology of Health and Illness, 27(5), pp. 602-627.

Melese, H. et al. (2020) 'Prevalence and Associated Factors of Musculoskeletal Disorders Among Cleaners Working at Mekelle University, Ethiopia", Journal of Pain Research, 13, pp. 2239-2246.

Ministry of Industry of Republic of Indonesia (2021) Batik Indonesia Masih Lebih Baik, Jakarta: Ministry of Industry of Republic of Indonesia.

National Center for Biotechnology Information (2016) Reactive Blue 19, Bethesda: National Center for Biotechnology Information.

Nesticò, A. et al. (2018) 'The ALARP Principle in the Cost-Benefit Analysis for the Acceptability of Investment Risk', Sustainability, 10(12), pp. $1-22$.

Nkwocha, A. C., Ekeke, I. C. and Olele, P. . (2018) 'Health, Safety and Environment in Oil and Gas', International Journal of Engineering Applied Sciences and Technology, 3(7), pp. 51-56.

Osborne, S. and Hammoud, M. S. (2017) 'Effective Employee Engagement in the Workplace', International Journal of Applied Management and Technology, 16(1), pp. 50-67.

Saisandhiya, N. R. (2020) 'Hazard Identification and Risk Assessment in Petrochemical Industry', International Journal for Research in Applied Science and Engineering Technology, 8(9), pp. 778-783.

Santa Cruz Biotechnology (2011a) Material Safety Data Sheet : Reactive Orange 16.

Santa Cruz Biotechnology (2011b) Material Safety Data Sheet : Reactive Red 120.

Sari, S. R., Lubis, M. Y. and Aisha, A. N. (2015) 'Perancangan Prosedur Untuk Meminimasi Risiko K3 Berdasarkan Hasil HIRARC untuk Memenuhi Requirement OHSAS 18001:2007 Klausul 4.4.7 Dan 4.5.1 Serta Peraturan Pemerintah No. 50 Tahun 2012 Di Rumah Batik Komar', e-Proceeding of Engineering, 2(2), pp. 4952 4959.

Shanker, R. et al. (2017) 'Organizational Climate for Innovation and Organizational Performance: The Mediating Effect of Innovative Work Behavior', Journal of Vocational Behavior. 100(June), pp. $67-77$.
Soebaryo, R. W. and Budianti, W. K. (2020) 'Batik Manufacturing Workers', in John, S. M. et al. (eds) Kanerva's Occupational Dermatology. Switzerland: Springer International Publishing, pp. 1743-1751.

Soltanzadeh, A. et al. (2016) 'Key Factors Contributing to Accident Severity Rate in Construction Industry in Iran: A Regression Modelling Approach', Arhiv za Higijenu Rada i Toksikologiju, 67(1), pp. 47-53.

Sumardiyono et al. (2014) 'Effectiveness of Ergonomic Chair against Musculoskeletal Disorders in Female Batik Workers of Sragen District', Makara Journal Health Research, 18(2), pp. 95-102.

Suprihatin, H. (2014) 'Kandungan Organik Limbah Cair Industri Batik Jetis Sidoarjo Dan Alternatif Pengolahannya', Jurnal Kajian Lingkungan, 2(2), pp. 130-138.

Susilowati, I. H. et al. (2017) 'Predictive Factors for Quality of Life Among Small and Medium Enterprise Workers in Indonesia', Asian Journal of Applied Sciences, 10(3), pp. 116-125.

The Institution of Occupational Safety and Health (IOSH) (2016) Musculoskeletal Disorders, Wigston: The Institution of Occupational Safety and Health (IOSH).

Trixie, A. A. (2020) 'Filosofi Motif Batik Sebagai Identitas Bangsa Indonesia', Folio, 1(1).pp. 1-9.

UNESCO (2009) Indonesian Batik, Paris: United Nations Educational, Scientific and Cultural Organization (UNESCO).

US EPA (2009) Risk Assessment Guidance for Superfund Volume I: Human Health Evaluation Manual (Part F, Supplemental Guidance for Inhalation Risk Assessment), Office of Superfund Remediation and Technology Innovation Environmental Protection Agency. Washington D.C: Environmental Protection Agency.

Walden, J., Jung, E. H. and Westerman, C. Y. K. (2017) 'Employee Communication, Job Engagement, and Organizational Commitment: A Study of Members of the Millennial Generation', Journal of Public Relations Research, 29(2-3), pp. 73-89.

Williams, O. S., Hamid, R. A. and Misnan, M. S. (2019) 'Causes of Building Construction Related Accident in the South-Western States of Nigeria', International Journal of Built Environment and Sustainability, 6(1), pp. 14-22.

De Winne, S. et al. (2019) 'The Impact of Employee Turnover and Turnover Volatility on Labor Productivity: A Flexible Non-Linear Approach', 
International Journal of Human Resource Management, 30(21), pp. 3049-3079.

Yiu, N. S. N. et al. (2019) 'Implementation of Safety Management System in Managing Construction Projects: Benefits and Obstacles', Safety Science, 117, pp. 23-32.

Yoon, S. J. et al. (2013) 'Effect of Occupational Health and Safety Management System on Work-Related Accident Rate and Differences of Occupational Health and Safety Management
System Awareness between Managers in South Korea 's Construction Industry', Safety and Health at Work, 4(4), pp. 201-209.

Zaharee, M. et al. (2018) 'Recruitment and Retention of Early-Career Technical Talent: What Young Employees Want from Employers A Study of the Workplace Attributes that Attract Early-Career Workers Suggests that Millennials may not be so Different from Earlier Generations.', Research Technology Management, 61(5), pp. 51-61. 